\title{
Minho River tidal freshwater wetlands: threats to faunal biodiversity
}

\author{
Ronaldo Sousa $^{1,2, *}$, Sérgia Costa Dias ${ }^{1,2}$, Lúcia Guilhermino ${ }^{1,2}$, Carlos Antunes ${ }^{1,3}$ \\ ${ }^{1}$ CIMAR/CIIMAR - Centro Interdisciplinar de Investigação Marinha e Ambiental, Universidade do Porto, \\ Rua dos Bragas 289, 4050-123 Porto, Portugal \\ ${ }^{2}$ ICBAS - Instituto de Ciências Biomédicas de Abel Salazar, Universidade do Porto, Lg. Prof. Abel Salazar 2, $4099-003$ Porto, \\ Portugal \\ ${ }^{3}$ Aquamuseu do Rio Minho, Parque do Castelinho, 4920-290 Vila Nova de Cerveira, Portugal
}

\begin{abstract}
Tidal freshwater wetlands (TFWs) support a characteristic type of community and perform fundamental environmental and ecological functions, however, studies conducted in this type of habitat are scarce and very fragmented. In the present paper, an overview of the TFW diversity and conservation state in the Minho River is provided, including temporal comparisons documenting indigenous fish and macrozoobenthos (principally mollusc) declines and information about the introduction of non-indigenous invasive species. We also discuss how this study can be exemplary of the actual ecological and conservational conditions of TFWs and the alarming present rates of indigenous biodiversity losses. Other TFW areas with comparable characteristics are probably under similar pressure and should therefore also be considered for conservation purposes. Better management of the flow regime, prohibition of construction near the margins, definition of more restricted areas for fishing, prohibition of some fisheries activities in defined periods of the year, enforcement of inspection, an increase in education and information for fishermen and local populations, and restoration of degraded habitats are some practical measures that should be implemented to mitigate this situation.
\end{abstract}

KEY WORDS: Tidal freshwater wetlands · Minho River estuary · Biodiversity · Conservation · Non-indigenous invasive species

\section{INTRODUCTION}

Estuaries are critical transition zones that link land, freshwater habitats and the sea (Day et al. 1989, Herman et al. 1999). These areas are usually recognised by their high productivity and the presence of habitats with conservation interest. Simultaneously, a considerable number of estuarine ecosystems represent some of the most anthropogenically-degraded habitat types on earth (McLusky 1999). These areas were originally selected for human settlement due to the proximity of freshwater sources, prevalence of fertile soils for agriculture, high fish, crustacean and shellfish productivity, and good accessibility via rivers to upstream regions (Edgar et al. 2000). Growing human popula- tions were responsible for an increasing number of industries, growth of ports and massive urban developments. As expected, this concentration of human activities has caused considerable environmental changes and compromised the biodiversity of these natural estuarine communities.

Recently, the health of coastal and estuarine ecosystems has entered the agendas of environmental managers and politicians. Several measures have been undertaken in an attempt to reduce the pressure on these systems, allowing the return to natural conditions or at least to improve the present situation. Certainly, pristine conditions will never be restored, but great improvement is still possible. The European Union Directive 2000/60/EC (Water Framework Direc- 
tive) is a good illustration of the efforts and financial investments that are now being expended in order to reverse the situation (Borja et al. 2004). In fact, there were improvements in the water quality of several aquatic ecosystems after the adoption of restoration actions (Eertman et al. 2002, Van den Bergh et al. 2005, Borja et al. 2006). However, this progress may not be sufficient to enable the return of the original biological community, since several new impacts are currently responsible for significant ecological changes in estuarine communities (e.g. biological invasions, climate change). These new challenges will mark the political and scientific agenda in the near future (Carlton \& Geller 1993, Cohen \& Carlton 1998, Sala et al. 2000).

One of the most neglected habitats inside estuarine ecosystems are tidal freshwater wetlands (TFWs). These limnetic areas have been subjected to few multidisciplinary studies when compared, for example, with brackish areas (Attrill \& Rundle 2002, Findlay et al. 2006). However, TFWs are fundamental ecosystems comprising essential habitats for several species with a high economic and/or conservation importance. Furthermore, TFWs are the connection between true freshwater ecosystems and the adjacent marine areas and are subjected to a mosaic of different abiotic conditions responsible for great heterogeneities, allowing their colonisation by a diverse fauna. In addition, these ecosystems are recognised as essential passages for commercially and conservationally important migratory fish species; they offer nursery conditions or refuges from predators for juvenile fish, molluscs and crustaceans; they provide essential feeding and drinking grounds for an important number of birds; and the presence of submerged and riparian vegetation creates several ideal habitats for a high number of both vertebrate and invertebrate species (Levin et al. 2001, Durell et al. 2005, West et al. 2005).

In the present paper, data from Minho River TFWs are provided and discussed as an example of biodiversity loss. Special attention is given to significant temporal differences observed in the abundance, biomass and diversity of animal species (principally molluscs and fishes) and to the introduction of non-indigenous invasive species (NISs). Several hypotheses on possible factors contributing to the present situation are discussed.

\section{MATERIALS AND METHODS}

Study area. The Minho River originates in Serra da Meira, in the province of Lugo (Spain) and drains into the Atlantic Ocean. It is $>300 \mathrm{~km}$ long, the last $70 \mathrm{~km}$ of which comprises its international section (the natural border between Portugal and Spain). Its hydro- logical basin has an area of $17080 \mathrm{~km}^{2}, 95 \%$ of which is located in Spain, and only $5 \%$, in Portugal.

The Minho River estuary is located on the northwest coast of the Iberian Peninsula and has a maximum width of just over $2 \mathrm{~km}$. This mesotidal estuary is partially mixed; however, during the period of high floods, it tends to evolve towards a salt wedge estuary (Sousa et al. 2005). The influence of spring tides extends approximately $40 \mathrm{~km}$ upstream, and the TFWs are located in the upper $30 \mathrm{~km}$. These TFWs include biotypes with mobile and rocky substrata, favourable to the occurrence of various types of organisms. River walls and other landscape features provide rocky substrates. Biotypes with mobile substrata occur in intertidal and subtidal areas and comprise areas close to the riverbanks, extensive sand and mud flats, inlets which form small bays, and marsh areas existing at the margins and on various islands. The Minho estuary is part of a Natura 2000 site, which includes the entire international section of the river. In the last years, several studies, especially focused on macroinvertebrates and fish species, were carried out in this estuary to characterize the main environmental and ecological processes (Sousa et al. 2005, 2007b, 2008, in press).

Sampling and data analysis. The literature cites containing abiotic and biotic data for the area under study were compiled as thoroughly as possible.

The current abiotic characterization of the TFWs of the Minho River was carried out using 2 different strategies: samples gathered at 16 sites (Fig. 1) along the total area of the Minho River TFWs in October of 2004, 2005, 2006 and 2007, and monthly samples taken at Sites 9, 11 and 12 (Fig. 1) from January to December 2005. At each site, the water parameters temperature $(\mathrm{T})$, conductivity (CND), total dissolved solids (TDS), redox potential (ORP), salinity (S), dissolved oxygen (DO) and $\mathrm{pH}$ were registered close to the bottom with a multiparameter probe YSI 6820. Water samples were also collected at intermediate depth to determine the concentration of nitrites, nitrates, ammonia, phosphates and water hardness. The concentrations of these parameters were determined by colorimetric methods using the Palintest 270 standard photometer 7000 . The sediment granulometry, which was divided in 6 size classes: very coarse sand (VCS), coarse sand (CS), medium sand (MS), fine sand (FS), very fine sand (VFS) and silt + clay (SC); and the organic matter (OM) content of sediments were determined using the methodology described by Sousa et al. (2006). In addition, the monthly inflow of the Minho River measured at the Foz do Mouro hydrometric station (INAG, www.inag.pt) was used to determine the degree of annual river inflow, using the available data from 1990 onwards.

Qualitative data available for the distribution of mollusc species collected at the beginning of the 20th cen- 


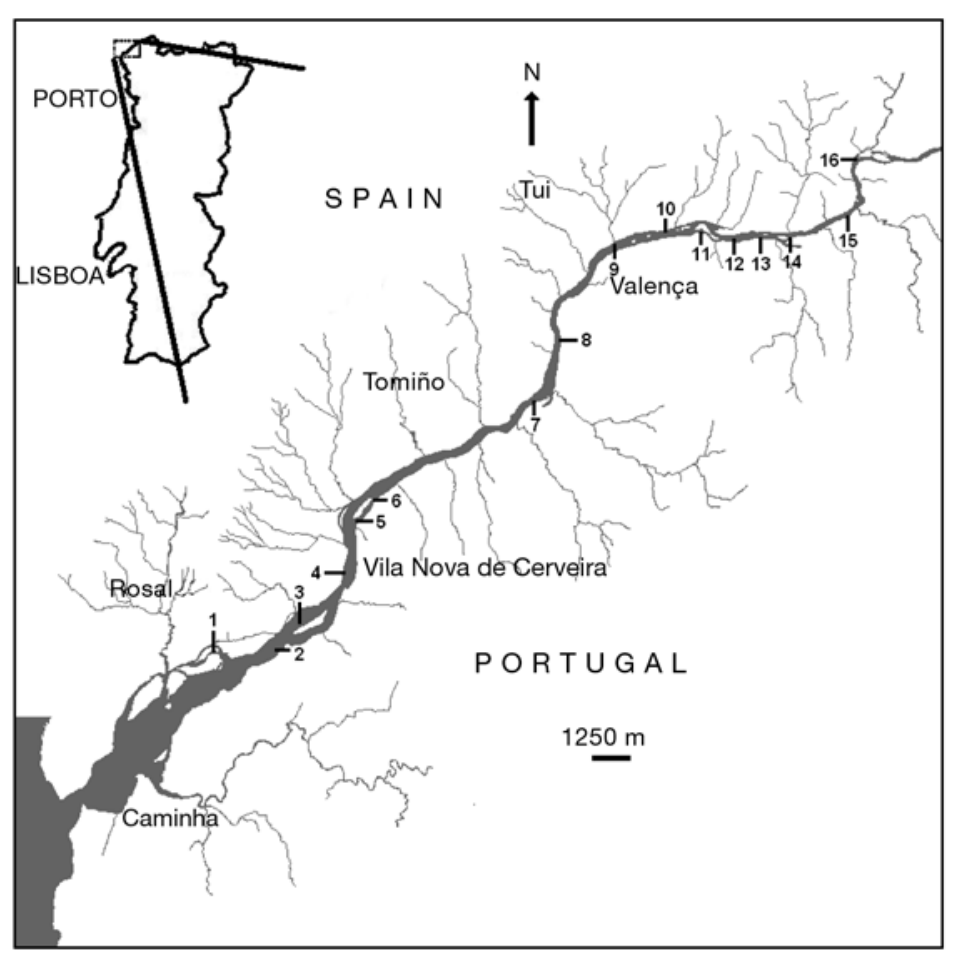

Fig. 1. Map of the Minho River estuary showing the tidal freshwater wetland (TFW; Sites 1 to 16) locations used for the abiotic and biotic characterization

tury (Nobre 1941), qualitative and quantitative data on the macrozoobenthos estuarine community distribution collected in 1977 and 1978 (Baños 1978) and 1989 (Maze et al. 1993) and qualitative data collected in 1990 and 1991 dealing with molluscs (Araujo et al. 1993, 1999) were used as baseline information about the assemblages colonising the Minho River TFWs and offer a general benchmark for the macrozoobenthos community that existed throughout the 20th century. These earlier studies were compared with data gathered in 2004, 2005, 2006 and 2007 at the same 16 sites (Fig. 1) indicated for the abiotic characterization (Sousa et al. 2005, 2007b, 2008, in press).

Some qualitative data on fish species were obtained from Antunes \& Weber (1996), Tola \& Infiesta (2002), Antunes \& Rodrigues (2004), and also from unpublished studies carried out by the authors of the present paper. Quantitative information on fish species abundance is scarce. Fisheries within the estuary include a vast area of the TFWs and so were employed as indicative of temporal variations. Fisheries data were obtained from official Portuguese statistics, and were used assuming a constant error in catch declarations among the years. It was not possible to calculate effective fishing effort, since a single license applies to different target species and catch values correspond to the overall fishing season per species; thus, yearly total catch values are presented. According to the data available (from the early 1980s onwards), the number of registered licensed boats has decreased slightly, but in an irregular trend, with a mean value in this period of 469 boats (minimum of 391 and maximum of 562).

\section{RESULTS}

\section{Abiotic characterization}

Unfortunately, the earlier studies done in Minho River TFWs have an irregular and incomplete abiotic characterization (Baños 1978, Maze et al. 1993, Araujo et al. 1999). So, the characterization of Minho River TFWs is restricted to recent studies (Sousa et al. 2005, 2007b, 2008, in press), and a general description is given in Tables $1 \& 2$. The sites sampled are distributed along a physical and chemical gradient, from the lower to the upper estuarine areas. Downstream sites are characterized by higher values of conductivity, salinity and total dissolved solids compared with upstream sites, which is consistent with the more pronounced influence of adjacent marine conditions. There is great spatial variation in the granulometry and organic matter content of the sediments along the TFWs. In relation to concentrations of nitrates, nitrites, ammonia and phosphates, the values reported can be considered lower when compared to other estuarine areas. However, the values may increase in some areas, in particular in the vicinity of agricultural fields and in one tributary (the Louro River) with higher organic pollution.

The location of the TFWs within the estuary depends on the balance between water volume and velocity of the incoming tide and the discharge of the out-flowing river. Given the high seasonal oscillation in the river discharge (INAG, www.inag.pt), the limits of the TFWs are highly variable: during high discharge, the tidal limit may be much further downstream than during low discharge.

The available data for pollutants showed low concentrations. For example, previous studies reported total concentrations of 17 different polybrominated diphenyl ether congeners in sediments at 4 different sites located along the international river section (1 site located in the adjacent coastal area) ranging from 0.3 to $4.8 \mathrm{ng} \mathrm{g}^{-1}$ (Lacorte et al. 2003). Recent data also showed low heavy metal concentrations $(\mathrm{Cd}, \mathrm{Cr}$, $\mathrm{Cu}, \mathrm{Ni}, \mathrm{Pb}$ and $\mathrm{Zn}$ ) measured in the sediments and Corbicula fluminea (Müller, 1774) tissues at 6 different sites (Sites 1, 4, 9, 11, 12 and 13; Fig. 1) in the TFWs (R. Sousa et al. unpubl. data). 


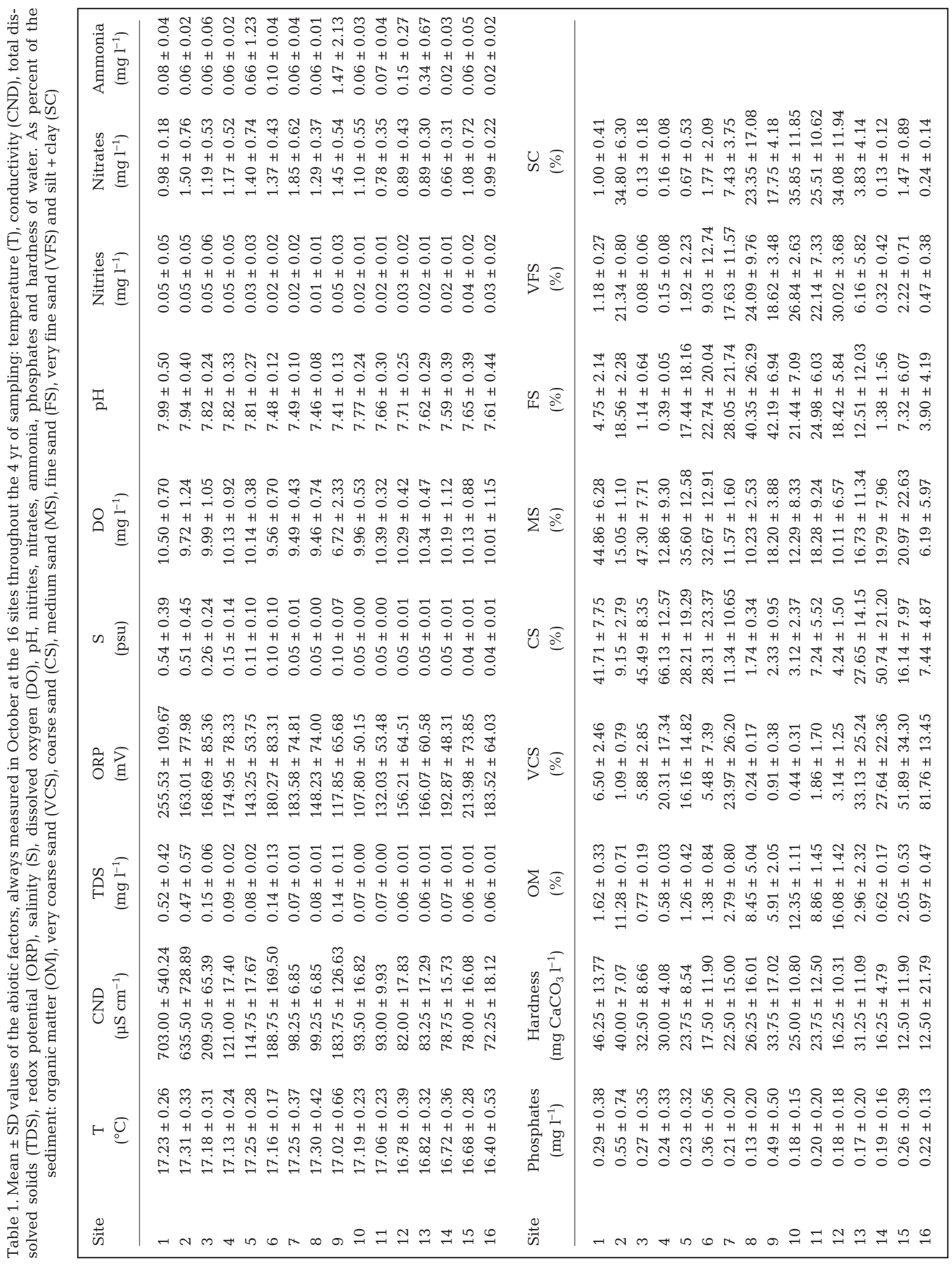


Table 2. Mean, maximum and minimum values of the abiotic factors measured monthly from January to December 2005 at Sites 9, 11 and 12: temperature (T), conductivity (CND), total dissolved solids (TDS), redox potential (ORP), salinity (S), dissolved oxygen (DO), $\mathrm{pH}$, nitrites, nitrates, ammonia, phosphates and hardness of water. As percent of the sediment: organic matter (OM), very coarse sand (VCS), coarse sand (CS), medium sand (MS), fine sand (FS), very fine sand (VFS) and silt + clay (SC)

\begin{tabular}{|c|c|c|c|c|c|c|c|c|c|c|}
\hline & $\begin{array}{c}\mathrm{T} \\
\left({ }^{\circ} \mathrm{C}\right)\end{array}$ & $\begin{array}{c}\mathrm{CND} \\
\left(\mu \mathrm{S} \mathrm{cm}^{-1}\right)\end{array}$ & $\begin{array}{c}\text { TDS } \\
\left(\mathrm{mg} \mathrm{l}^{-1}\right)\end{array}$ & $\begin{array}{l}\text { ORP } \\
(\mathrm{mV})\end{array}$ & $\begin{array}{c}\mathrm{S} \\
(\mathrm{psu})\end{array}$ & $\begin{array}{c}\mathrm{DO} \\
\left(\mathrm{mg} \mathrm{l}^{-1}\right)\end{array}$ & $\mathrm{pH}$ & $\begin{array}{l}\text { Nitrites } \\
\left(\mathrm{mg} \mathrm{l}^{-1}\right)\end{array}$ & $\begin{array}{l}\text { Nitrates } \\
\left(\mathrm{mg} \mathrm{l}^{-1}\right)\end{array}$ & $\begin{array}{c}\text { Ammonia } \\
\left(\mathrm{mg} \mathrm{l}^{-1}\right)\end{array}$ \\
\hline \multicolumn{11}{|l|}{ Site 9} \\
\hline Mean & 15.8 & 131.8 & 0.1 & 114.1 & 0.1 & 6.3 & 7.3 & 0.1 & 1.3 & 0.9 \\
\hline Maximum & 22.8 & 169.0 & 0.2 & 192.4 & 0.1 & 10.8 & 7.8 & 0.2 & 2.2 & 2.4 \\
\hline Minimum & 7.4 & 89.0 & 0.1 & 9.5 & 0.1 & 4.6 & 7.1 & 0.0 & 0.8 & 0.1 \\
\hline \multicolumn{11}{|l|}{ Site 11} \\
\hline Mean & 15.5 & 82.8 & 0.1 & 91.1 & 0.0 & 9.9 & 7.7 & 0.0 & 1.1 & 0.2 \\
\hline Maximum & 23.1 & 115.0 & 0.1 & 197.0 & 0.1 & 12.7 & 7.9 & 0.1 & 2.2 & 1.9 \\
\hline Minimum & 6.7 & 66.0 & 0.1 & 23.3 & 0.0 & 8.1 & 7.4 & 0.0 & 0.6 & 0.0 \\
\hline \multicolumn{11}{|l|}{ Site 12} \\
\hline Mean & 15.1 & 79.8 & 0.1 & 110.0 & 0.0 & 9.9 & 7.7 & 0.0 & 0.9 & 0.0 \\
\hline Maximum & 22.2 & 114.0 & 0.1 & 272.4 & 0.1 & 12.6 & 7.9 & 0.1 & 1.4 & 0.1 \\
\hline \multirow[t]{2}{*}{ Minimum } & 6.9 & 67.0 & 0.1 & 16.5 & 0.0 & 7.3 & 7.3 & 0.0 & 0.0 & 0.0 \\
\hline & $\begin{array}{l}\text { Phosphates } \\
\left(\mathrm{mg} \mathrm{l}^{-1}\right)\end{array}$ & $\begin{array}{c}\text { S Hardness } \\
\left(\mathrm{mg} \mathrm{CaCO}_{3} \mathrm{l}^{-1}\right)\end{array}$ & $\begin{array}{l}\mathrm{OM} \\
(\%)\end{array}$ & $\begin{array}{l}\text { VCS } \\
(\%)\end{array}$ & $\begin{array}{l}\mathrm{CS} \\
(\%)\end{array}$ & $\begin{array}{l}\text { MS } \\
(\%)\end{array}$ & $\begin{array}{l}\text { FS } \\
(\%)\end{array}$ & $\begin{array}{l}\text { VFS } \\
(\%)\end{array}$ & $\begin{array}{l}\mathrm{SC} \\
(\%)\end{array}$ & \\
\hline \multicolumn{11}{|l|}{ Site 9} \\
\hline Mean & 0.3 & 19.2 & 7.2 & 0.3 & 1.1 & 10.8 & 37.9 & 28.2 & 21.7 & \\
\hline Maximum & 0.6 & 35.0 & 10.7 & 0.6 & 2.2 & 18.3 & 45.0 & 37.3 & 29.2 & \\
\hline Minimum & 0.2 & 5.0 & 6.0 & 0.1 & 0.6 & 5.8 & 26.9 & 21.2 & 16.4 & \\
\hline \multicolumn{11}{|l|}{ Site 11} \\
\hline Mean & 0.2 & 30.4 & 10.7 & 0.7 & 2.4 & 9.5 & 22.0 & 29.7 & 35.8 & \\
\hline Maximum & 1.1 & 70.0 & 13.9 & 2.4 & 5.1 & 12.3 & 27.7 & 35.5 & 41.1 & \\
\hline Minimum & 0.0 & 10.0 & 8.7 & 0.2 & 1.0 & 6.2 & 18.1 & 23.4 & 25.7 & \\
\hline \multicolumn{11}{|l|}{ Site 12} \\
\hline Mean & 0.1 & 18.3 & 16.9 & 1.2 & 2.6 & 9.3 & 14.1 & 30.9 & 42.0 & \\
\hline Maximum & 0.1 & 70.0 & 19.3 & 2.9 & 5.3 & 15.1 & 16.7 & 38.8 & 45.1 & \\
\hline Minimum & 0.0 & 5.0 & 14.6 & 0.2 & 1.0 & 4.0 & 8.9 & 24.5 & 37.0 & \\
\hline
\end{tabular}

\section{Macrozoobenthos decline}

The comparison of earlier (Nobre 1941, Baños 1978, Araujo et al. 1993, 1999) with recent (Sousa et al. 2005, 2007b, 2008, in press) macrozoobenthos studies showed differences, principally, in the molluscan composition. In Table 3, the molluscan community that could easily be found 20 yr ago is shown and compared with data collected in several surveys performed recently. It should be noted that the sampling effort was much higher in the studies performed in the last 4 yr than in the earlier studies. In summary, the earlier TFW molluscan community supported a rich bivalve fauna consisting of several large species of freshwater mussels from the Margaritiferidae and Unionidae families, clams from the Shaeriidae family and gastropod species. Freshwater mussel species such as Unio pictorum (Linnaeus, 1758), Anodonta cygnea (Linnaeus, 1758), Anodonta anatina (Linnaeus, 1758), Psilunio littoralis (Lamarck, 1801) and Margaritifera margaritifera (Linnaeus, 1758) (none found in TFWs in the last few years, but still present in a nearby upstream tributary) are nowadays very rare, and the abundance and biomass of these species are now a small remnant of those recorded years ago. Other bivalve species such as Pisidium amnicum, Pisidium subtruncatum (Malm, 1855), Pisidium casertanum (Poli, 1791), Pisidium henslowanum (Sheppard, 1823), Pisidium milium (Held, 1836) and Musculium lacustre (Müller, 1774) (none of the last 3 species were found in the Minho River TFWs in the last few years) were described by several authors in earlier studies (Nobre 1941, Baños 1978, Araujo et al. 1993, 1999). Additionally, the gastropod species Gyraulus albus (Müller, 1774) was not found in the last 4 yr. Nowadays the TFW molluscan community is completely dominated by the presence of the NIS Corbicula fluminea. This species dominates the benthic biomass of the estuarine area accounting for $>95 \%$ of it (Sousa et al. 2005, 2007b, 2008, in press). This alteration in the molluscan community occurred in 1989 when this NIS was introduced (Araujo et al. 1993). Molluscan data collected recently (Sousa et al. 
Table 3. Mollusc species (X: present) described for the Minho estuary TFWs in earlier (Nobre 1941, Baños 1978, Araujo et al. 1993, 1999, Maze et al. 1993) and recent (Sousa et al. 2005, 2007b, 2008, in press) studies

\begin{tabular}{|llcc|}
\hline & Freshwater molluscs & $\begin{array}{c}\text { Earlier } \\
\text { studies }\end{array}$ & $\begin{array}{c}\text { Recent } \\
\text { studies }\end{array}$ \\
\hline 1 & Margaritifera margaritifera (Linnaeus, 1758) & $\mathrm{X}$ & \\
2 & Psilunio littoralis (Lamarck, 1801) & $\mathrm{X}$ & $\mathrm{X}$ \\
3 & Unio pictorum (Linnaeus, 1758) & $\mathrm{X}$ & $\mathrm{X}$ \\
4 & Anodonta anatina (Linnaeus, 1758) & $\mathrm{X}$ & $\mathrm{X}$ \\
5 & Anodonta cygnea (Linnaeus, 1758) & $\mathrm{X}$ & $\mathrm{X}$ \\
6 & Corbicula fluminea (Müller, 1774) & $\mathrm{X}$ & $\mathrm{X}$ \\
7 & Pisidium amnicum (Müller, 1774) & $\mathrm{X}$ & $\mathrm{X}$ \\
8 & Pisidium casertanum (Poli, 1791) & $\mathrm{X}$ & $\mathrm{X}$ \\
9 & Pisidium henslowanum (Sheppard, 1823) & $\mathrm{X}$ & \\
10 & Pisidium milium (Held, 1836) & $\mathrm{X}$ & $\mathrm{X}$ \\
11 & Pisidium subtruncatum (Malm, 1855) & $\mathrm{X}$ & \\
12 & Musculium lacustre (Müller, 1774) & $\mathrm{X}$ & $\mathrm{X}$ \\
13 & Ancylus fluviatilis (Müller, 1774) & $\mathrm{X}$ & $\mathrm{X}$ \\
14 & Bithynia tentaculata (Linnaeus, 1758) & $\mathrm{X}$ & $\mathrm{X}$ \\
15 & Gyraulus laevis (Alder, 1838) & $\mathrm{X}$ & \\
16 & Gyraulus albus (Müller, 1774) & $\mathrm{X}$ & $\mathrm{X}$ \\
17 & Lymnaea peregra (Müller, 1774) & $\mathrm{X}$ & $\mathrm{X}$ \\
18 & Physella acuta (Draparnaud, 1805) & $\mathrm{X}$ & $\mathrm{X}$ \\
19 & Potamopyrgus antipodarum (Gray, 1843) & $\mathrm{X}$ & $\mathrm{X}$ \\
20 & Valvata piscinalis (Müller, 1774) & $\mathrm{X}$ & $\mathrm{X}$ \\
21 & Succinea putris (Linnaeus, 1758) & & \\
aOnly 2 individuals found in the last 4 yr. The species identification was \\
based on morphological characteristics only (possible taxonomical \\
confusion with Anodonta anatina) & & \\
\hline
\end{tabular}

2007b) show a significant decline in the diversity, abundance and biomass during the 2005 summer (Fig. 2). The abiotic conditions of 2005 were responsible for massive mortalities in benthic species (primarily in C. fluminea, followed by the rest of the benthic assemblage). Indeed, 2005 was a very dry year on the Iberian Peninsula, and a considerable reduction of the discharge of the Minho River was recorded. In that summer several abiotic alterations occurred in the upper estuarine limnetic areas: an increase in the water temperature and a decrease in the water flow, redox potential and dissolved oxygen (Sousa et al. 2007b, 2008). This occurrence was especially dramatic for the molluscan species, and recruitment in the subsequent years was not sufficient to recover the prior abundance and diversity (Table 4). However, our data also show that the NIS $C$. fluminea rapidly recovered from this impact, but, up to now, the other molluscan species have not returned to their previous numbers or distribution (Table 4).
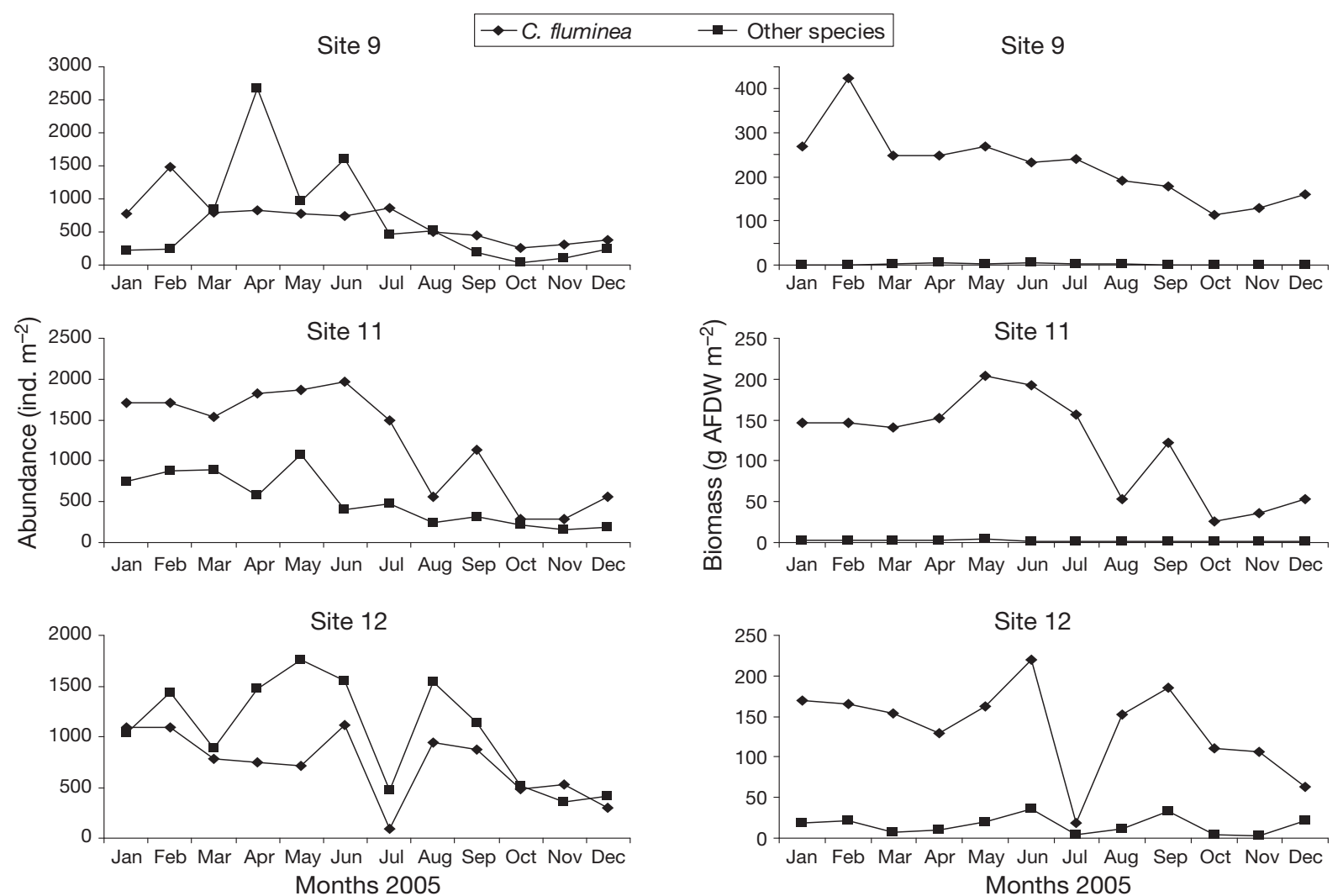

Fig. 2. Mollusc declines (abundance and biomass) after the 2005 summer heatwave (data obtained at Sites 9, 11 and 12). Data are divided in Corbicula fluminea and all other species of molluscs. For further information about this study see Sousa et al. (2007b). AFDW: ash-free dry weight 
Table 4. Data on molluscs (number of species, and total and Corbicula fluminea abundance and biomass) from sampling surveys performed at 16 sites (see Fig. 1 for locations) in October 2004, 2005, 2006 and 2007. AFDW: ash-free dry weight

\begin{tabular}{|rrrrrr|}
\hline & $\begin{array}{c}\text { No. of } \\
\text { species }\end{array}$ & \multicolumn{2}{c}{$\begin{array}{c}\text { Abundance } \\
\text { (ind. }{ }^{-2} \text { ) } \\
\text { Total }\end{array}$} & \multicolumn{2}{c|}{$\begin{array}{c}\text { Biomass } \\
\text { C. fluminea }\end{array}$} \\
\hline 2004 & 10 & 1412 & 1256 & 98.4 & 95.2 \\
2005 & 13 & 1049 & 956 & 100.7 & 99.1 \\
2006 & 9 & 1082 & 1062 & 122.7 & 121.4 \\
2007 & 7 & 1303 & 1283 & 161.6 & 161.0 \\
\hline
\end{tabular}

In other macrozoobenthos groups, differences are not as significant. Crustacean and insect species present in Minho River TFWs have changed little between earlier and recent studies. However, data available from previous studies are almost exclusively composed by qualitative data. Species from transition areas between fresh and more saline waters are still present nowadays and in some places with a high abundance; e.g. Corophium multisetosum (Stock, 1952), Gammarus chevreuxi (Sexton, 1913). Nevertheless, a clear reduction in the distribution and abundance of Gammarus pulex (Linnaeus, 1758), a true freshwater species, can be noted by comparison between recent data (Sousa et al. in press) and the results of 1977 and 1978 surveys (Baños 1978). Additionally, the native crayfish Austropotamobius pallipes (Lereboullet, 1858) also disappeared and was replaced by the NIS Procambarus clarkii (Girard, 1852).

\section{Fish decline}

The ichthyofauna of the Minho estuary has been the subject of discontinuous studies for the last 25 yr (Antunes 1994, Antunes \& Weber 1996). TFWs are significantly used by economically important fish species such as Anguilla anguilla (Linnaeus, 1758) and Platichthys flesus (Linnaeus, 1758) in key periods of their life cycles. In a recent study, it was pointed out that the epibenthic $P$. flesus population present in the Minho estuary has its main nursery ground in the TFWs (Cabral et al. 2007). In this area, the species Salmo trutta fario (Linnaeus, 1758) and Chondrostoma polylepis (Steindachner, 1866), appreciated as game fish, may also be found. Although without commercial value, other ecologically important species, such as Gasterosteus aculeatus (Linnaeus, 1758), Rutilus arcasii
(Steindachner, 1866), Leuciscus carolitertii (Doadrio, 1988) and Cobitis paludica (De Buen, 1930), inhabit such areas.

When trying to compare the actual fish species composition with those that could be found in TFW conditions existing decades ago, the lack of quantitative data in the earliest surveys prevents detailed comparisons. Although there are no recent records of Lampetra fluviatilis (Linnaeus, 1758), Lampetra planeri (Bloch, 1784) and Acipenser sturio (Linnaeus, 1758) in the Minho River, Almaça \& Elvira (2000) and Tola \& Infiesta (2002) refer to those species as being historically present in this river. On the other hand, some fish species were introduced for various purposes, mainly in the last few years, and are now easily found in TFWs (Table 5).

Diadromous species, such as the anadromous Salmo salar (Linnaeus, 1758), Salmo trutta trutta (Linnaeus, 1758), Petromyzon marinus (Linnaeus, 1758), Alosa alosa (Linnaeus, 1758) and Alosa fallax (Lacepède, 1803) and the above-mentioned catadromous Platichthys flesus and Anguilla anguilla (exploited both as glass and yellow eels), form the list of the most economically important species for traditional fishery in the Minho estuary. Even taking into consideration the error inherent to fisheries statistics (Antunes \& Weber 1996), the decline in fish catches is evident (Fig. 3). The exception seems to be fisheries data for $P$. marinus. This species fishery, however, comprises a wider

Table 5. Non-indigenous invasive species (NISs) recorded in the Minho estuary. The origin of the species and their category based on the definitions of Carlton (1992) are given

\begin{tabular}{|c|c|c|c|}
\hline & NIS & Origin & Category \\
\hline 1 & Corbicula fluminea (Müller, 1774) & Asia & Established \\
\hline 2 & Physella acuta (Draparnaud, 1805) & North America ${ }^{\mathrm{a}}$ & Established \\
\hline 3 & Potamopyrgus antipodarum (Gray, 1843) & New Zealand & Established \\
\hline 4 & Eriocheir sinensis (Milne Edwards, 1853) & Asia & $\begin{array}{c}\text { Established, } \\
\text { not certain }\end{array}$ \\
\hline 5 & Procambarus clarkii (Girard, 1852) & North America & Established \\
\hline 6 & Carassius auratus (Linnaeus, 1758) & Euroasia & Established \\
\hline 7 & Cyprinus carpio (Linnaeus, 1758) & Asia & Established \\
\hline 8 & Gambusia holbrooki (Girard, 1859) & North America & Established \\
\hline 9 & Gobio gobio (Linnaeus, 1758) & Euroasia & Established \\
\hline 10 & Lepomis gibbosus (Linnaeus, 1758) & North America & Established $?^{\mathrm{b}}$ \\
\hline 11 & Micropterus salmoides (Lacepède, 1802) & North America & Established \\
\hline 12 & Onchorhynchus mykiss (Walbaum, 1792) & North America & Established \\
\hline 13 & Phoxinus phoxinus (Linnaeus, 1758) & Euroasia & $\begin{array}{c}\text { Established, } \\
\text { not certain }\end{array}$ \\
\hline 14 & Tinca tinca (Linnaeus, 1758) & Euroasia & Established \\
\hline 15 & Myopsitta monachus (Boddaert, 1783) & South America & Established \\
\hline 16 & Estrilda astrild (Linnaeus, 1758) & Africa & Established \\
\hline 17 & Estrilda troglodytes (Lichtenstein, 1823) & Africa & Established \\
\hline 18 & Mustela vison (Schreber, 1777) & North America & Established \\
\hline
\end{tabular}



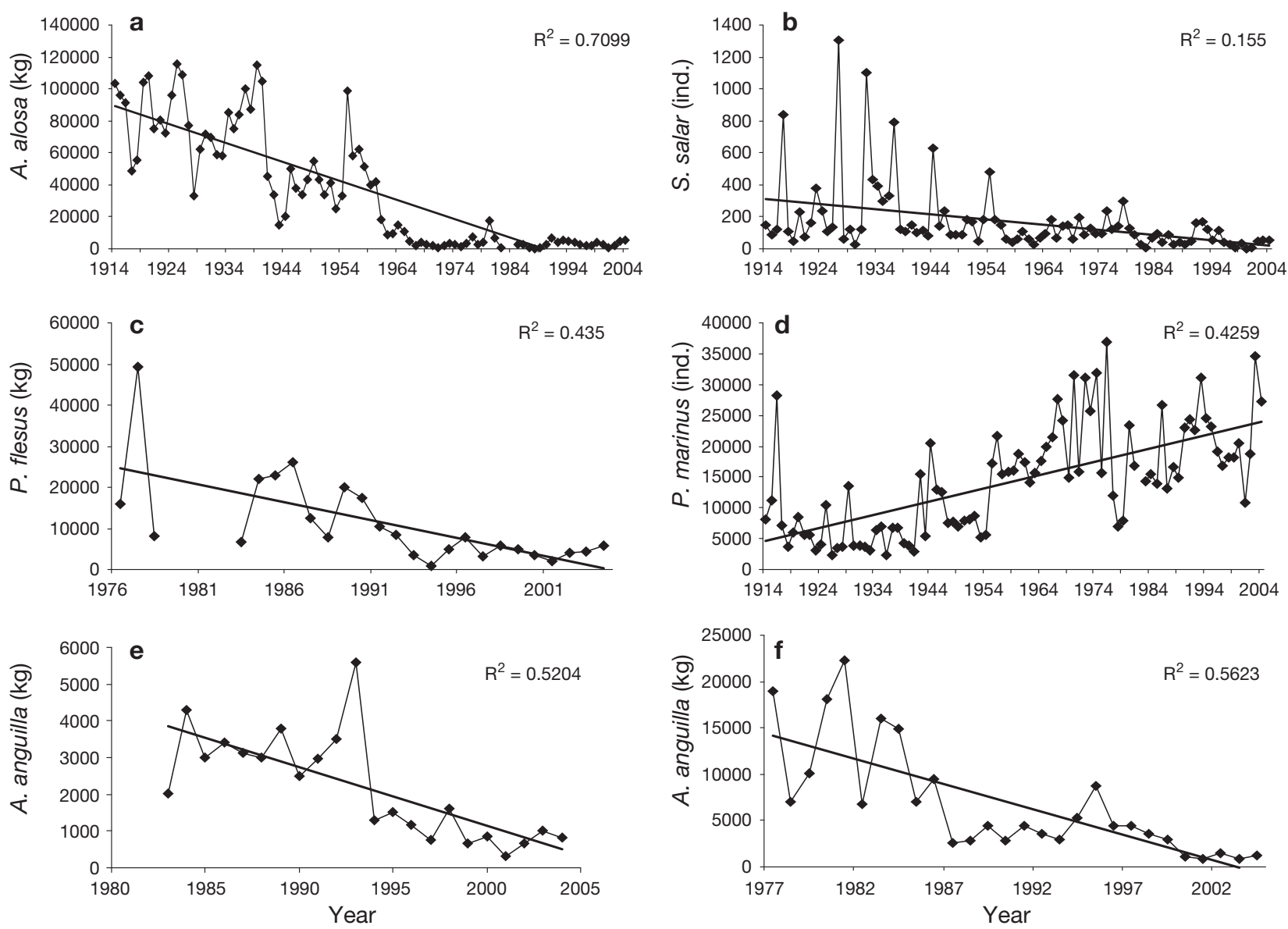

Fig. 3. Fisheries trends in the Minho River (data based on official Portuguese authorities' statistics): (a) Alosa alosa (kg), (b) Salmo salar (ind.), (c) Platichthys flesus (kg), (d) Petromyzon marinus (ind.), (e) Anguilla anguilla-as yellow eel (kg) and (f) Anguilla anguilla - as glass eel $(\mathrm{kg})$. Highly significant relationships $(\mathrm{p}<0.01)$ were obtained for all species

catching area, and the method for data collection is reported to have changed over time.

\section{Non-indigenous invasive species}

For the Minho estuary, the presence of 18 nonindigenous animal species has been recorded (Table 5), and the introduction sources were clearly human (e.g. fish introduction for sports fisheries and the use of macroinvertebrates as fish bait). Of those 18 non-indigenous species, 15 are well established and have self-sustaining populations; only the mitten crab Eriocheir sinensis (Milne Edwards, 1853) and the Eurasian minnow Phoxinus phoxinus (Linnaeus, 1758) appear to have failed to establish themselves after having been observed in this estuarine area. In addition, Lepomis gibbosus (Linnaeus, 1758) was recorded for the first time in April 2007, and the successful establishment of this NIS has yet to be studied.
The major problems concerning NISs are related to the enormous abundance and biomass attained by Corbicula fluminea. The ecology of C. fluminea has been investigated recently, and detailed data is provided in Sousa et al. (2005, 2007a,b, 2008, in press). This NIS is distributed throughout TFWs, colonising all types of soft sediments. For the years 2004, 2005, 2006 and 2007, the mean abundance and biomass were $>1000$ ind. $\mathrm{m}^{-2}$ and $100 \mathrm{~g}$ ash-free dry weight (AFDW) $\mathrm{m}^{-2}$, respectively. The gastropods Physella acuta (Draparnaud, 1805) and Potamopyrgus antipodarum (Gray, 1843) also have a great spatial distribution in the Minho River TFWs, but their abundance and biomass are a small fraction of that previously measured for $C$. fluminea (Sousa et al. 2005, 2007b). The crustacean species Procambarus clarkii is also a common inhabitant. This NIS is also very abundant, being widely distributed in the TFWs and in several small tributaries. Possibly, this species was responsible for the disappearance of the native crayfish Austropotamobius pallipes in the Minho River TFWs (due to interspecific 
competition and infection with crayfish plague). Nine fish species were introduced in the last years, and some of them have been able to attain high abundance and biomass, such as Cyprinus carpio (Linnaeus, 1758), Micropterus salmoides (Lacepède, 1802) and Tinca tinca (Linnaeus, 1758). Finally, 3 species of birds: Estrilda astrild (Linnaeus, 1758), Estrilda troglodytes (Lichtenstein, 1823) and Myopsitta monachus (Boddaert, 1783); and the mammal Mustela vison (Schreber, 1777), have also been described as recent colonisers. However, the abundance, biomass and distribution of these populations have yet to be determined since the information available is scarce.

\section{DISCUSSION}

\section{Abiotic characterization}

The Minho estuary has been considered to be at a low chemical contamination level, not raising serious concern. For this reason, it has been used as a reference site in several ecotoxicological studies performed on the NW coast of Portugal (e.g. Moreira et al. 2006, 2007, Elumalai et al. 2007). The main sources of environmental contaminants are fluvial traffic (e.g. small fishery and tourist boats, ferry boats connecting Portugal to Spain), agricultural fields, some industries mainly in tributaries of the Minho River, and urban effluents of relatively small towns and villages discharged into the river without previous treatment.

The construction of dams and the potential impacts of climate change could be responsible for the decrease in river discharge, which may alter the limits of the Minho River TFWs. This decrease in river discharge could alter the abiotic conditions (e.g. increase in salinity and conductivity), principally at the downstream limit of the Minho River TFWs, and be responsible for alterations in faunal assemblages. In addition, climatic events could also be responsible for huge abiotic changes creating problems for faunal assemblages. For example, during the dry summer of 2005, a reduction in water flow and an increase in water temperature coincided. Consequently, decreases in redox potential and dissolved oxygen occurred in the upstream estuarine areas with very fine sediments and rich in organic matter content, resulting in massive mortalities in the benthic species and water deterioration (Sousa et al. 2007b, 2008).

\section{Conservation status}

In recent years the number of extinctions in freshwater ecosystems has dramatically increased and the concern about this phenomenon is now emerging as a global ecologic and conservation problem (Ricciardi \& Rasmussen 1999). A closer look at global conservation studies demonstrates that some faunistic groups are more susceptible to extinction than others. Data available in the IUCN Red List of Threatened Species (www.redlist.org) points out the great conservational concern for mollusc and fish species. Our results also show that molluscs and fish species present in the Minho River TFWs are particularly threaten by extinction, and this situation deserves more attention. In the Minho River TFWs, indigenous freshwater mussel species are nowadays very rare and the abundance and biomass are now vestigial when compared to those recorded in earlier studies. Freshwater mussels are declining at unprecedented rates and are the core of several freshwater conservation studies done principally in North America (Lydeard et al. 2004, Strayer et al. 2004). This circumstance is very problematic due to specific traits (e.g. extended life spans, delayed maturity, reduced power of dispersal, great juvenile mortalities, long turnover times, the larvae [glochidia] are obligate parasites of fish species and the settlement appears to be particularly affected by environmental changes) that render freshwater mussels especially vulnerable to habitat disturbance. These traits make it considerably more difficult for the successful implementation of conservation measures taken in an advanced phase of the problem and, therefore, require urgent intervention. Of the 5 freshwater mussel species found in the Minho River hydrological basin, only Margaritifera margaritifera has been subjected to multidisciplinary studies in Europe, due to its importance in conservation (Hastie et al. 2000, Reis 2003). Special protection and increased ecological information are likewise needed for bivalve species from the Sphaeriidae family and gastropods that are also subject to extirpation in the Minho River TFWs. Nowadays, the TFW molluscan community is completely dominated by the NIS Corbicula fluminea. Consequently, one of the most important aspects to be studied in the Minho River TFWs is the possible change in ecosystem functioning (i.e. how this NIS altered previous ecological processes) (Hakenkamp \& Palmer 1999, Hakenkamp et al. 2001, Vaughn \& Hakenkamp 2001). This global decline in molluscan diversity, abundance, biomass and distribution and the replacement of indigenous species by NISs have been described in several freshwater (Lydeard et al. 2004, Strayer et al. 2004) and marine (Edgar \& Samson 2004, Edgar et al. 2005) ecosystems. In relation to other macrozoobenthos groups, the differences are not as clear, due to scarcity of studies and because the existent earlier data are only qualitative. Consequently, further discussion may be speculative. 
As in many other European TFWs, the autochthonous fish community present in the Minho River seems to be declining. TFWs constitute a vital migratory corridor for diadromous species migrating for either feeding or spawning and these ecosystems are considered conduits of nutrients travelling in different directions (from rivers to ocean and vice versa). This general decline has been attributed to several anthropogenic pressures that mainly prevented migration paths or access to suitable habitats, thus, affecting the species' life cycle. Although the total number of fish species may have increased in the Minho River TFWs due to introduced NISs, the decrease in the number and abundance of native species is evident. Considering fisheries data, catches seem to have generally been declining over the last few decades, but values cannot be directly interpreted and some additional considerations are necessary. Only the decrease in Alosa alosa has clearly been related to a specific impact in the Minho River basin, such as dam construction (Taverny et al. 2000), but generally decreasing trends have also been described on a worldwide scale for Salmo salar and Anguilla anguilla. These patterns may show, e.g., evidence of a general deterioration of habitat suitability or overexploitation, but the origins of these trends are not restricted to TFWs given the specificity of the life cycles of these migratory fish species.

\section{Principal threats}

Estuaries are frequently recognized as heavily impacted ecosystems. These impacts are usually described as single pressures, but in the majority of cases they have synergistic effects. In the Minho River TFWs, the main problems follow the general trend described for other ecosystems, namely, habitat loss, introduction of NISs, climate change, impoundments and river regularizations, fishing activities and pollution.

Habitat loss is the most common threat to biodiversity (Rodrigues et al. 2006). Estuaries are not an exception since they are constantly subject to changes due to natural and anthropogenic-mediated processes. Loss in area and physical and chemical changes in the Minho River TFWs include alteration in the habitats due to construction of ditches, channels, roads, railways, houses, or other types of construction (several times in flood areas). The existence of dams or other types of impoundments in areas upstream of the Minho River TFWs also has inevitable repercussions that may include fragmentation of a once continuous ecosystem.

The introduction of NISs is one of the most important threats to aquatic environments, with potentially catastrophic ecological and economic impacts (Ricciardi \& MacIsaac 2000, Grosholz 2002, Kolar \& Lodge 2002).
Given the characteristics of the species that have been invading this estuary, the ecosystem characteristics, the evolution of anthropogenic activities and the predicted global changes, more invasions are expected to occur in the near future. For the macroinvertebrates, the major concern in these TFWs is the ecological and economic impacts provoked by Corbicula fluminea and Procambarus clarkii (Sousa et al. 2005, 2007b, 2008, in press). In relation to non-indigenous fish species, the main problems are the possible impacts of piscivorous species (e.g. Micropterus salmoides), with potential top down effects in the estuarine food chain, and of abundant and large species (e.g. Cyprinus carpio and Tinca tinca) preying upon already altered invertebrate assemblages and physically changing the habitat. The other faunal NISs have relatively low abundance and/or occupy trophic niches for which low pressure or competition exists, and, therefore, their impacts seem to be less severe. However, the actual situation may change quickly depending on the community's readjustment to a new or an increased source of stress.

Given the present tendency for the increase of temperature, the occurrence of droughts and floods will tend to be much more pronounced in the future (Humphries \& Baldwin 2003). However, since the Minho River does not have a natural regime due to anthropogenic interventions, this situation could be mitigated by appropriate manipulations of the flow (McMahon \& Finlayson 2003). Possible climate changes in this area may be disastrous for several species well adapted to the present abiotic conditions. In this scenario, the species currently having their southern distribution limit in the Minho River (e.g. Pisidium amnicum) will probably be the first to disappear, and the future estuarine community will have characteristics more close to those of southern estuaries. Heatwaves, which may include an increase in seasonal and supra-seasonal drought conditions, can have a dramatic impact on estuarine communities, particularly in sensitive areas such as TFWs. The impacts caused by the 2005 heatwave in the molluscan community of the Minho River TFWs are a good example of that, and a similar situation has been described in other ecosystems (Mouthon \& Daufresne 2006).

Although not independent of natural conditions, the flow regime within the Minho hydrological basin is subject to human control, and the same is true of numerous worldwide hydrological basins (Lytle \& Poff 2004). The Minho River hydrological basin has $>50$ dams or other kinds of impoundments that have caused great impacts on the natural river flow, created obstacles to migratory fish species and fragmented the habitats. The last $70 \mathrm{~km}$ of the main river does not have any impoundments, but suffers the consequences of upstream regularizations. This situation is responsible 
for great daily flow oscillations that result in both abnormally high and low flows. In reality, the Minho River TFWs are not only subjected to the 2 normal tides, but also to daily discharge by the upstream Frieira dam. Because streams are basically linear systems, the altered flow and consequent changes in other abiotic conditions directly downstream of impoundments should display a gradual change in the ecosystem (Vaughn \& Taylor 1999). These impacts may have disastrous effects in benthic and pelagic communities, introducing, for example, a novel stress factor by flushing downstream developing larvae or juveniles, or even adults that are not able to avoid displacement, and by changing the sediment composition.

Inland fisheries have lost much of their significance in Europe and North America (Allan et al. 2005). In western Europe the number of professional fishermen has decreased significantly in the last few decades, but inland fisheries have continued to have both social and financial significance. In addition, these activities have been replaced by sport fisheries, which also have a great economic importance and significant potential for expansion in the future. In the Minho River TFWs several fish species have medium (Salmo trutta, Alosa fallax, Platichthys flesus and Anguilla anguilla as yellow eel) or high (Salmo salar, Alosa alosa, Petromyzon marinus and Anguilla anguilla as glass eel) economic value. Statements from the local population and official records of captures for some of these species indicate significant declines in recent decades, and inland fisheries may have some responsibility for that. Nowadays, inland fisheries have restrictive regulations, but fishing gear confiscation allows us to say that illegal fishery activities occur achieving uncertain, but presumably high, catches. Although drastic reductions in population size as well as local extinctions attributed to fisheries have been recorded for many species, documented cases of global extinctions in estuaries and coastal waters are extremely rare, being the result of overfishing sometimes combined with poor water quality (Blaber et al. 2000). In the Minho estuary, fishing pressure does not seem to act as a single, isolated factor leading to stock impoverishment, but acting synergistically with other causes, including habitat disturbance.

Pollution can also contribute to the loss of biodiversity. It can cause the exclusion of sensitive species that are not able to survive or to adapt to certain levels of pollution, can alter abiotic factors to which some species have a low range of tolerance, or can interfere in interspecific relationships (e.g. inducing mortality, decreasing the predatory or escape capabilities, or weakening defences against competitors, diseases and parasites). As a result of anthropogenic pressure, a considerable portion of the world's estuaries are now facing pollution problems. Heavy metals, petrochemical products, pesticides, butyltin compounds and nutrients are common estuarine pollutants (Turner \& Rabalais 1994, Voorspoels et al. 2004, Díaz et al. 2007). In addition, the so-called 'emergent pollutants of concern' (e.g. pharmaceuticals, polychlorinated dibenzop-dioxins, polychlorinated dibenzofurans, polychlorinated biphenyls, polychlorinated naphthalenes, perfluorinated chemicals and brominated flame retardants) have been noted in estuarine and coastal areas (de Boer et al. 1998, Eljarrat \& Barceló 2003). At present, pollution does not seem to be a great threat in the Minho River TFWs, and the deterioration of water quality has never reached the dramatic situation described for other estuarine areas.

\section{Management issues}

The Minho River TFWs have a great ecological and economic importance, at least at the regional level. The main problems recognised as potential threats to this estuarine area are also identified as the major problems in other ecosystems.

The introduction of NISs is one of the most important threats to this estuarine ecosystem. The arrival of other NISs is very difficult to predict and control, but some measures could be implemented (i.e. education and information for fishermen and local populations, taking advantage of local infrastructure devoted to environmental education). In addition, good ecological monitoring of the estuary could detect introductions in the early phases of development and eradicate such NISs with increased success.

The major problems in dealing with fishing activities are related to migratory species that have great economic importance. Local authorities, fishermen and scientists all agree that several practices that can be easily adopted could have great results and improve the actual situation. Among others, the definition of more restricted areas for fishing, both at the river's mouth and in the margins of upstream areas, may increase the upstream migration chances for diadromous fish species and their movements to the nursery grounds (e.g. Alosa alosa, A. fallax, Platichthys flesus, Petromyzon marinus). Also, the prohibition of some fisheries activities in defined periods of the year, the licensing of catch permission and limits, the obligation to declare fish catches and, obviously, enforcing inspection are possible protection measures.

Problems caused by loss and fragmentation of habitat, global warming and river regularization are much more difficult to solve, since some are global problems and are impossible to revert, at least in a short-term period. Although, in relation to the loss and fragmenta- 
tion of habitats, local authorities can play a major role. Construction near the margins of the Minho River TFWs should clearly be prohibited, given the vital functions taking place in these areas (e.g. mitigation of floods, nursery areas for several fish and macrozoobenthos species). Dams and river regulation activities are difficult to deal with, especially since this is an international river that is the natural border between Portugal and Spain for $>70 \mathrm{~km}$. Removing large installations is obviously almost impossible due to political and economic interests. However, the oscillations in the flow regime caused by impoundments could be better managed by a consensual water policy. Furthermore, the removal of small inactive impoundments that still exist in the tributaries of the international section of the Minho River could increase the availability of habitats (migratory species would certainly take advantage if these actions were adopted).

Finally, restoration of the degraded habitats can lead to re-establishment of some species and improved inland and coastal water quality, and can provide new areas for wildlife habitat and recreational activities (Palmer et al. 2004, Bernhardt et al. 2005). This kind of practice needs financial investment, but, even more importantly, huge planning efforts involving scientists, managers, politicians and local populations (Ewel et al. 2001).

\section{CONCLUSIONS}

The problem of biodiversity loss in TFW ecosystems is now a fact, but this issue has received negligible attention from conservation, political and management groups, overlooking the actual ecological situation of these habitats and the biodiversity crisis in freshwater ecosystems. The actual rates of extinction of freshwater species will have numerous consequences, with varying severity, depending on the ecosystem. A progressive reduction in biodiversity means that fewer species will be present to perform crucial functions, and the consequences could be disastrous when species having a special influence on biogeochemical cycles, energy fluxes and trophic dynamics are lost (Allan et al. 2005).

In the Minho River TFWs the major conservation problems are associated with migratory fish and molluscan species (following the trend already described in the IUCN Red List of Threatened Species) and the introduction of NISs. This estuarine area is within a protected area that belongs to the Natura 2000 sites. However, effective protection is not provided, since this area continues to suffer several impacts. Portugal and Spain should collaborate in order to effectively preserve this ecosystem, and some possible measures of protection have been described above. Moreover, raising awareness concerning the state of these areas is needed, and further knowledge should be gathered by greater scientific investment in a multidisciplinary way.

The long-term advantages of an effective protection of the Minho River TFWs include shoreline protection, water quality improvement and mitigation of flood impacts and can directly benefit activities like fisheries, tourism, agriculture and hunting, among others. Additionally, there is an aesthetic value that should be preserved and a moral obligation to prevent biodiversity loss in these ecosystems.

Acknowledgements. R.S. and S.C.D. were supported by PhD grants from the Portuguese Foundation for Science and Technology - FCT (SFRH/BD/18426/2004 and SFRH/BD/16922/ 2004, respectively). Special thanks to Eduardo Martins for field assistance, to Jonathan Wilson for his revision of the manuscript and to the Capitania of Caminha for fisheries data. Detailed comments from anonymous reviewers were also highly appreciated and helped to improve an earlier version of the manuscript.

\section{LITERATURE CITED}

Allan JD, Abell R, Hogan Z, Revenga C, Taylor BW, Welcomme RL, Winemiller K (2005) Overfishing of inland waters. Bioscience 55:1041-1051

Almaça C, Elvira B (2000) Past and present distribution of Acipenser sturio L., 1758 on the Iberian Peninsula. Bol Inst Esp Oceanogr 16:11-16

>Antunes C (1994) The seasonal occurrence of glass eels (Anguilla anguilla L.) in the Rio Minho between 1991 and 1993 (north of Portugal). Int Rev Gesamten Hydrobiol 79:287-294

Antunes C, Rodrigues H (2004) Guia Natural do Rio MinhoOs peixes. Aquamuseu do Rio Minho, Vila Nova de Cerveira

Antunes C, Weber M (1996) The glass eel fishery and the by-catch in Rio Minho after one decade (1981-1982 and 1991-1992). Arch Pol Fish 4:131-139

Araujo R, Moreno D, Ramos MA (1993) The asiatic clam Corbicula fluminea (Müller, 1774) (Bivalvia: Corbiculidae) in Europe. Am Malacol Bull 10:39-49

Araujo R, Ramos MA, Molinet R (1999) Growth pattern and dynamics of a southern peripheral population of Pisidium amnicum (Müller, 1774) (Bivalvia: Sphaeriidae) in Spain. Malacologia 41:119-137

Attrill MJ, Rundle SD (2002) Ecotone or ecocline: ecological boundaries in estuaries. Estuar Coast Shelf Sci 55:929-936

Baños JPM (1978) Aportación al estudio del macrobentos y polución física en el Bajo Miño. BSc thesis, Universidade de Santiago de Compostela, Spain

Bernhardt ES, Palmer MA, Allan JD, Alexander G and others (2005) Synthesizing U.S. river restoration efforts. Science 308:636-637

Blaber SJM, Cyrus DP, Albaret JJ, Ching CV and others (2000) Effects of fishing on the structure and functioning of estuarine and nearshore ecosystems. ICES J Mar Sci 57: 590-602

Borja A, Franco J, Valencia V, Bald J, Muxika I, Belzunce MJ, 
Solaun O (2004) Implementation of the European water framework directive from the Basque country (northern Spain): a methodological approach. Mar Pollut Bull 48: 209-218

Borja A, Muxika I, Franco J (2006) Long-term recovery of softbottom benthos following urban and industrial sewage treatment in the Nervión estuary (southern Bay of Biscay). Mar Ecol Prog Ser 313:43-55

Cabral HN, Vasconcelos R, Vinagre C, França S and others (2007) Relative importance of estuarine flatfish nurseries along the Portuguese coast. J Sea Res 57:209-217

Carlton JT (1992) Introduced marine and estuarine mollusks of North America: an end-of-the-20th-century perspective. J Shellfish Res 11:489-505

Carlton JT, Geller JB (1993) Ecological roulette: the global transport of nonindigenous marine organisms. Science 261:78-83

Cohen AN, Carlton JT (1998) Accelerating invasion rate in a highly invaded estuary. Science 279:555-558

Day W, Hall AS, Kemp W, Yánez-Arancibia A (1989) Estuarine ecology. Wiley-Interscience Publication, New York

de Boer J, Wester PG, Klamer HC, Lewis WE, Boon JP (1998) Do flame retardants threaten ocean life? Nature 394: 28-29

> Díaz J, Higuera-Ruiz R, Elorza J, Irabien A, Ortiz I (2007) Distribution of butyltin and derivatives in oyster shells and trapped sediments of two estuaries in Cantabria (northern Spain). Chemosphere 67:623-629

- Durell SEA, McGrorty S, West AD, Clarke RT, Goss-Custard JD, Stillman RA (2005) A strategy for baseline monitoring of estuary special protection areas. Biol Conserv 121: 289-301

Edgar GJ, Samson CR (2004) Catastrophic decline in mollusc diversity in eastern Tasmania and its concurrence with shellfish fisheries. Conserv Biol 18:1579-1588

Edgar GJ, Barrett NS, Graddon DJ, Last PR (2000) The conservation significance of estuaries: a classification of Tasmanian estuaries using ecological, physical and demographic attributes as a case study. Biol Conserv 92: 383-397

Edgar GJ, Samson CR, Barrett NS (2005) Species extinction in the marine environment: Tasmania as a regional example of overlooked losses in biodiversity. Conserv Biol 19: $1294-1300$

Eertman RHM, Kornman BA, Stikvoort E, Verbeek H (2002) Restoration of the Sieperda tidal marsh in the Scheldt Estuary, The Netherlands. Restor Ecol 10:438-449

Eljarrat E, Barceló D (2003) Priority lists for persistent organic pollutants and emerging contaminants based on their relative toxic potency in environmental samples. Trends Analyt Chem 22:655-665

Elumalai M, Antunes C, Guilhermino L (2007) Enzymatic biomarkers in the crab Carcinus maenas from the Minho River estuary (NW Portugal) exposed to zinc and mercury. Chemosphere 66:1249-1255

Ewel KC, Cressa C, Kneib RT, Lake PS and others (2001) Managing critical transition zones. Ecosystems 4:452-460

Findlay SEG, Nieder WC, Blair EA, Fischer DT (2006) Multiscale controls on water quality effects of submerged aquatic vegetation in the tidal freshwater Hudson River. Ecosystems 9:84-96

> Grosholz E (2002) Ecological and evolutionary consequences of coastal invasions. Trends Ecol Evol 17:22-27

> Hakenkamp CC, Palmer MA (1999) Introduced bivalves in freshwater ecosystems: the impact of Corbicula on organic matter dynamics in a sandy stream. Oecologia 119: $445-451$
Hakenkamp CC, Ribblett SG, Palmer MA, Swan CM, Reid JW, Goodison MR (2001) The impact of an introduced bivalve (Corbicula fluminea) on the benthos of a sandy stream. Freshw Biol 46:491-501

- Hastie LC, Young MR, Boon PJ, Cosgrove PJ, Henninger B (2000) Sizes, densities and age structures of Scottish Margaritifera margaritifera (L.) populations. Aquat Conserv 10:229-247

Herman PMJ, Middelburg JJ, Van de Koppel J, Heip CHR (1999) Ecology of estuarine macrobenthos. Adv Ecol Res 29:195-240

Humphries P, Baldwin DS (2003) Drought and aquatic ecosystems: an introduction. Freshw Biol 48:1141-1146

> Kolar CS, Lodge DM (2002) Ecological predictions and risk assessment for alien fishes in North America. Science 298: $1233-1236$

Lacorte S, Guillamón M, Martínez E, Viana P, Barceló D (2003) Occurrence and specific congener profile of 40 polybrominated diphenyl ethers in river and coastal sediments from Portugal. Environ Sci Technol 37:892-898

- Levin LA, Boesch DF, Covich A, Dahm C and others (2001) The function of marine critical transition zones and the importance of sediment biodiversity. Ecosystems 4:430-451

Lydeard C, Cowie RH, Ponder WF, Bogan AE and others (2004) The global decline of nonmarine mollusks. Bioscience 54:321-330

Lytle DA, Poff NL (2004) Adaptation to natural flow regimes. Trends Ecol Evol 19:94-100

Maze RA, Lastra M, Mora J (1993) Macrozoobentos del estuario del Miño (NO de España). Publ Espec Inst Esp Oceanogr 11:283-290

> McLusky D (1999) Estuarine benthic ecology: a European perspective. Aust J Ecol 24:302-311

> McMahon TA, Finlayson BL (2003) Droughts and antidroughts: the low flow hydrology of Australian rivers. Freshw Biol 48:1147-1160

- Monteiro M, Quintaneiro C, Nogueira AJA, Morgado F, Soares AMVM, Guilhermino L (2007) Impact of chemical exposure on the fish Pomatoschistus microps Krøyer (1838) in estuaries of the Portuguese Northwest coast. Chemosphere 66:514-522

Moreira SM, Moreira-Santos M, Guilhermino L, Ribeiro R (2006) An in situ postexposure feeding assay with Carcinus maenas for estuarine sediment-overlying water toxicity evaluations. Environ Pollut 139:318-329

- Mouthon J, Daufresne M (2006) Effects of the 2003 heatwave and climatic warming on mollusc communities of the Saône: a large lowland river and of its two main tributaries (France). Glob Change Biol 12:441-449

Nobre A (1941) Fauna malacológica de Portugal. Moluscos terrestres e fluviais. Memórias e Estudos do Museu Zoológico, Universidade de Coimbra, Coimbra

Palmer M, Bernhardt E, Chornesky E, Collins S and others (2004) Ecology for a crowded planet. Science 304: $1251-1252$

Reis J (2003) The freshwater pearl mussel [Margaritifera margaritifera (L.)] (Bivalvia, Unionoida) rediscovered in Portugal and threats to its survival. Biol Conserv 114: 447-452

Ricciardi A, MacIsaac HJ (2000) Recent mass invasion of the North American Great Lakes by Ponto-Caspian species. Trends Ecol Evol 15:62-65

> Ricciardi A, Rasmussen JB (1999) Extinction rates of North American freshwater fauna. Conserv Biol 13:1220-1222

Rodrigues ASL, Pilgrim JD, Lamoreux JF, Hoffmann M, Brooks TM (2006) The value of the IUCN Red List for conservation. Trends Ecol Evol 21:71-76 
Sala OE, Chapin FS, Armesto JJ, Berlow E and others (2000) Global biodiversity scenarios for the year 2100. Science 287:1770-1774

Sousa R, Guilhermino L, Antunes C (2005) Molluscan fauna in the freshwater tidal area of the River Minho estuary, NW of Iberian Peninsula. Ann Limnol 41:141-147

Sousa R, Dias S, Antunes C (2006) Spatial subtidal macrobenthic distribution in relation to abiotic conditions in the Lima estuary, NW of Portugal. Hydrobiologia 559:135-148 Sousa R, Freire R, Rufino M, Méndez J, Gaspar M, Antunes C, Guilhermino L (2007a) Genetic and shell morphological variability of the invasive bivalve Corbicula fluminea (Müller, 1774) in two Portuguese estuaries. Estuar Coast Shelf Sci 74:166-174

Sousa R, Antunes C, Guilhermino L (2007b) Species composition and monthly variation of the Molluscan fauna in the freshwater subtidal area of the River Minho estuary. Estuar Coast Shelf Sci 75:90-100

Sousa R, Rufino M, Gaspar M, Antunes C, Guilhermino L (2008) Abiotic impacts on spatial and temporal distribution of Corbicula fluminea (Müller, 1774) in the River Minho Estuary, Portugal. Aquat Conserv 18:98-110

Sousa R, Dias S, Freitas V, Antunes C (in press) Subtidal macrozoobenthic assemblages along the River Minho estuarine gradient (northwest Iberian Peninsula). Aquat Conserv, doi:10.1002/aqc.871

Strayer DL, Downing JA, Haag WR, King TL, Layzer JB, Newton TJ, Nichols SJ (2004) Changing perspectives on

Editorial responsibility: Riccardo Cattaneo-Vietti, Genova, Italy pearly mussels, North America's most imperiled animals. Bioscience 54:429-439

Taverny C, Belaud A, Elie P, Sabatié MR (2000) Influence des activités humaines. In: Baglinière JL, Elie $\mathrm{P}$ (eds) Les Aloses (Alosa alosa et Alosa fallax spp.). INRA, Paris, p 227-248

Tola J, Infiesta E (2002) Peces continentales de la Península Ibérica. Ediciones Jaguar SA, Madrid

Turner RE, Rabalais NN (1994) Coastal eutrophication near the Mississippi River delta. Nature 368:619-621

> Van den Bergh E, Van Damme S, Graveland J, de Jong D, Baten I, Meire P (2005) Ecological rehabilitation of the Schelde Estuary (The Netherlands-Belgium; Northwest Europe): linking ecology, safety against floods, and accessibility for port development. Restor Ecol 13:204-214

> Vaughn CC, Hakenkamp CC (2001) The functional role of burrowing bivalves in freshwater ecosystems. Freshw Biol 46:1431-1446

- Vaughn CC, Taylor CM (1999) Impoundments and the decline of freshwater mussels: a case study of an extinction gradient. Conserv Biol 13:912-920

> Voorspoels S, Covaci A, Maervoet J, De Meester I, Schepens P (2004) Levels and profiles of PCBs and OCPs in marine benthic species from the Belgian North Sea and the western Scheldt Estuary. Mar Pollut Bull 49:393-404

West AD, Goss-Custard JD, Durell SEA, Stillman RA (2005) Maintaining estuary quality for shorebirds: towards simple guidelines. Biol Conserv 123:211-224

Submitted: March 10, 2008; Accepted: June 19, 2008

Proofs received from author(s): August 25, 2008 